\title{
International Audit Standard No. 240 and Its Impact on the Practical Procedures of Auditors in Detection the Manipulation of Financial Statements
}

\author{
Dr. Haitham Mamdouh Abbadi \\ School of Business, Amman Arab University \\ Dr. Nimer Abedalhameed Slihat (Corresponding author) \\ School of Business, Amman Arab University \\ Email: drnimer1@ hotmail.com
}

DOI: 10.5296/ijafr.v5i1.7828 URL: http://dx.doi.org/10.5296/ ijafr.v5i1.7828

\begin{abstract}
This study aims to explore the role of International Audit Standard No.240 on the auditor's procedures in detecting manipulation and fraud of financial Statements, the descriptive approach was used in conducting this study, through viewing the related literature in order to indentify the practices that lead to manipulation. And by identifying the auditor's responsibilities according to the International Audit Standard No. 240. The results showed that firms may commit manipulation in several ways, such as recording the current expenses as capital expenses, to reduce costs and increase profits which may lead managers to ask for rewards. Therefore, the auditor must make greater efforts to the following:

- Focusing on financial events that have different accounting treatments, such as record maintenance expenses, at the fixed asset account. The purpose of this action is to reduce costs and increase profits, which may lead to request, a reward by managers.

- Comparing manager's Salaries with Past year.

- Comparing financial ratios of the company with its counterparts in the market.

- Send support certificates for suppliers to make sure their account balances, in order to ensure the registration of all Purchases futures in inventory account.
\end{abstract}

Keywords: International Audit Standard No. 240, Manipulation and Fraud, Financial Statements. 


\section{Macrothink}

\section{Introduction}

External audit aims to report that the financial statements published reflect the actual financial position of the firm through financial statements that are valid and credible. And the auditing report must stipulate on this aspect in order to reassure all stakeholders and especially shareholders. Credibility and integrity of financial statements can be achieved when they are free from fraud and manipulation. (Venten, 2003)

The importance of the detection fraudulent financial statements increased recently after the financial scandals that resulted in the bankruptcy of giant companies such as Enron, Xerox, WorldCom and Arthur Andersen, and etc. Some of firms are practicing several ways and accounting procedures to distort their financial statements for different objectives. This is done through deceptive practices based on the exploitation of the flexibility in the international accounting standards. Fraud and manipulation of financial statements involve the understatement or overstatement of some items in the financial statements for certain objectives in favor of the firm's managers, like getting rewards, tax evasion, reduce dividends to shareholders, and getting financing from banks. Therefore, managers may manipulate inventories, reserves and allowances; also, they may manipulate accruals in order to reduce the cost and increase the income, and many other practices. (Melumad and Nissim, 2008)

In order to overcome such practices, the Auditing Standards Board issued the Statement on auditing Standards (SAS) No. 240, Consideration of Fraud in a Financial Statement. This research aims to highlight the auditing procedures and activities that exercised by auditors to hand mode these manipulations and frauds.

\section{Problem Statement and questions:}

Despite the commitment of many of external auditors in applying international auditing standard No. 240, but there are many companies that are still practiced fraud in accounting operations which results in distorting the financial statements for the benefit of managers and harm the interests of the users of accounting information. In this regard, a lot of the related literature was focused on the objectives of fraud and maipulation in accounting operations. For example, Sapthis et al (2003), pointed out that senior managers might commit financial fraud to deceive lenders and investors, or to overstating in the company profits to gain higher salaries and bonuses.

Therefore, external auditors, who are considered the final reference to the integrity and credibility the company's financial statements, must have the ability to detect fraud and manipulation in these statements. This problem was discussed according to the following questions:

1. To what extent the commitment of the auditors in Jordan with the international standard No. 240?

2. Are the Scientific qualifications of the auditors consistent with the audit career?

3. Does the external auditor compare financial ratios of the company with their counterparts in the market to detect fraud?

4. Who is communicated by the external auditor at the discovery of cases of fraud? 


\section{$\triangle$ Macrothink}

\section{Research Objectives:}

This research aims to achieve the following:

1. To identify the degree of understanding and commitment of the external auditors in Jordan to the international standard No. 240.

2. Identification of audit procedures that help the external auditor in the discovery of fraud.

3. Determine the best ways in which the external auditor to detect fraud and reduce it in subsequent years.

\section{Research significance:}

The significance of this research stems from the significance of accounting information for several users, where these users take many financial decisions in the light of accounting information. And because these users rely on the published financial statements in making decisions, it becomes necessary that financial statements be free from fraud.

\section{Research methodology:}

5.1 Research type:

This research will be conducted under the descriptive approach by relying on data of previous studies, and the requirements of the application of the International Audit Standard No.240 .

\subsection{Data collection:}

Secondary data was collected from books and published articles, while the primary data was collected by designing and distributing the questionnaire attached with this research.

\subsection{Research Hypotheses:}

HA 1 : Application of International Audit Standard No. 240 enables the external auditor in detecting fraud and manipulation in inventory.

HA2: Application of International Audit Standard No. 240 enables the external auditor in detecting fraud and manipulation in expenses.

HA3: Application of International Audit Standard No. 240 enables the external auditor in detecting fraud and manipulation in accruals.

HA 3: Application of International Audit Standard No. 240 enables the external auditor in detecting fraud and manipulation in provisions and reserves. 


\section{The study Model:}

\begin{tabular}{|l|l|l|}
\hline \multicolumn{2}{|c|}{ Independent Variables } \\
\hline \hline Commitment to the International Audit \\
Standard No.240.
\end{tabular}

\section{Literature review and Theoretical Backgromal}

\subsection{Literatme Review:}

Reference to the related literature to the subject of this research, researchers found a large number of researches, where researchers chose the following previous studies:

1. Study by Kirkos et al (2007), under the title: "Data Mining Techniques for the Detection of Fraudulent Financial Statements".

The study aimed to investigate the usefulness of three data mining techniques, and to conducting a comparison between these techniques in terms of performance. The study was conducting on a sample contains data from 76 Greek manufacturing companies. And through analyzing the usefulness of the used techniques in fraud detection, where these techniques were; decision Trees, Neural Networks, and Bayesian Belief Network. The results of the study showed that published financial statement data contains falsification indicators, where data mining algorithms can provide knowledge about the accuracy of financial ratios. And, the accuracy rate for each technique was: Bayesian Belief Network 90.3\%, Neural Network $73.6 \%$, and decision Tree 80\%. Researchers have recommended prolong the time of audit.

2. Study by AL-Znaimat (2011), under the title: "The Impact of actual Audit Quality on the Effectiveness of Financial Statements Fraud Detecting in the Jordanian Auditing Sector".

The study aimed to discern the impact of audit quality on the effectiveness of the process of detecting manipulation and fraud in the financial statements. The study was conducted on a sample of 100 audit firms, and data was collected by distributing a questionnaire on the sample members. According to the study, audit quality was represented by technical competence, auditor's independence, and audit planning. Data was analyzed by using the multiple regression approach. The findings of the study showed that the auditing firms 
working in Jordan enjoy a high level of audit quality, and auditing firms working in Jordan heavily use fraud-detection red flags. Then, the research recommended the audit firms in Jordan to categorize many factors (mentioned earlier) to be as an auditing model that ensure the audit quality.

3. Study by Bierstaker et al (2006), under the title: “Accountants' Perceptions Regarding Fraud Detection and Prevention Methods".

The study aimed to specify the extent of using the methods of fraud prevention and fraud detection by accountants, internal auditors, and external auditors, and their assessment of the effectiveness of these methods. The study was conducted on a sample of 86 respondents from the three parties mentioned above. The results showed that firewalls, virus and password protection, and internal control review are commonly used to prevent fraud. But, discovery sampling and data mining, forensic accountants, and digital analysis software are not often useful. The main recommendation was to use cost/benefit analysis, because this may shed light the fraud flags.

4. Study by Alleyne and Howard (2005), underthe title: "An exploratory Study of auditors, Responsibility for fruad Detection in Barbados"

The study aimed to examine how the grasping of auditors and users and users to the auditor's responsibility for detecting fraud, the nature and extent of fraud in Barbados, and audit procedures utilized in Barbados Since Enron. The study was conducted on a sample consisted of 19 auditors and 24 users, who were Surveyed about their Views and experiences on fraud, using qualitative and quantitative approaches, the results showed a wide gap between the auditors and users, where auditors believe that the detection of fraud is management's responsibility, while users and management disagree. Also, the fraud is not a major practice in the country and that companies internal auditors, sound internal controls and effective audit committees can deal in active ways with fraud prevention and detection.

5. Study by Hammersley (2011) under the title: "A Reviewand Model of Auditor Judgments in Fraud. Related Planning Tasks."

This study aimed to develop a model that describes the characteristics of auditor, to deal with risk factors of fraud which are expected to affect the performance factors of fraud which are expected to affect the performance of the auditor. This qualitative study was conducted according to what was reported in many previous studies. The result showed that the Knowledge, especially fraud Knowledge, will significantly affect auditor performance in audit program modification tasks through its effects on fraud risk factor identification. This Knowledge can be acquired through, qualifications, direct experience in the same audit company. But the indirect experience such as training (out - of the - job training) may provide the auditor with better problem solving skills, and higher epistemic motivation.

6. Study by Abdullatif (2013), under the title: "Fraud Risk Factors and Audit Programme Modifications: Evidence from Jordan".

This study aimed to investigate how Jordanian audit firms deals with the presence, of fraud risk factors in audit clients. And which of risk factors are the most important to Jordanian auditors, and how the Jordanian auditors consider modifying the audit programmes when Fraud risk factors are present in the client. 
The study was conducted through distributing a questionnaire to senior level auditors in the largest Jordanian audit firms. The results of the study showed that all of the 20 fraud risk factors included in the questionnaire have weak importance, also, each fraud risk factor was related to the perceived importance of the fraud risk factor itself, and the most important fraud risk factors were related to the characteristics of management and its attitude towards the audit.

7. Study by Nawaiseh and Al- Oqda (2007) under the title: "Assisting factors in Detecting Audit Errors and Fraud: An Empirical Study from the Audit Bureau Auditor's Perspective."

The study aimed to analyze the assisting factors in detecting audit errors and fraud from the point of view of the auditors working in Adit Bureau. The study was conducted on a sample consists of 150 auditors through distributing a questionnaire by hand for the sample members 125 questionnaire were suitable for analysis purposes. The results of the statistical analysis showed that the most effective variables were the factors associated with independence, whether financially or administratively independent. While the lowest effect was to factors related to the upper management support.

\subsection{Theoretical background:}

Auditing profession gained paramount importance, especially after the global financial crisis that has beset many of the major companies such as Enron and World Com, as well as many of the giant in Amercan banks, where the cause for the occurrence of the global financial crisis was, to exploit the absence of the supervisory role of the U.S Federal Reserve, making banks expand in the granting of mortgage loans against mortgage of real estate collateral, not sufficient to ensure the value of loans, which can be called as a fraud Practice (Crotty, 2008). Accordingly many states and Professional commissions around the globe have issued rules and principles for corporate governance which focused on auditing processes whether internal or external.

Moreover, States, professional Commissions and Practitioners have realized the necessity of developing Scientific Principles for Practicing audit Profession in order to be as a guider for auditors. These trends led to issuing the international audit standards. Where the states have become required auditors to apply these standards, or, derived standards fit the environment.

Since this research revolves around the role of the auditor in detecting fraud in the financial statements, the International Standard No. 240 is the most important for the purpose of this research, because this International Standard on Auditing (I S A) 240 stipulates on: "The auditor responsibilities relating to fraud in an audit of financial statements" therefore it is necessary to allocate a separate topic within this chapter to discuss the consequences of the commitment to this standard on the work of the independent auditor.

\section{International standard on Auditing No. 240:}

Scope of ISA No. 240:

This International standard on Auditing could be considered as a guideline for auditors because of its dealing with the auditor's responsibilities relating to fraud in an audit of financial statements, and because it illustrates how to apply ISA No. 315 and ISA No. $330^{2}$ in relation to risks of material misstatement due to fraud. Also, this standard describes the 


\section{MInstitute Macrothink $_{\text {Int }}$}

International Journal of Accounting and Financial Reporting

characteristics of fraud through two main axes:

1- Misstatements in the financial statements can occur from either fraud or error. The Judging factor between fraud and error is whether the underlying action that results in the misstatements of financial statements is; intentional or unintentional. (Ismail and Prihatiningtyas, 2014)

2- Despite the great interest in fraud and manipulation by the laws, but for the purposes of International Auditing Standards, auditors are focusing on fraud that causes a material misstatement in the financial statements. The auditor attention goes to two types of misstatements; the first is misstatements resulting from fraudulent financial reporting, and second, misstatements resulting from misappropriation of assets. Although the auditor may doubt, or in rare cases may identify the occurrence of fraud, but he does not make legal determinants whether fraud has actually occurred, but he can take different steps such as the attempt to obtain additional evidence (Ramos, 2003). One may ask about the auditor responsibility in detection fraud in the financial statements, in such debate we must linkage between the objectives of auditing and auditor responsibilities (Di Gabriele, 2008).

Since the main objectives of the auditor are; identifying and assessing the risks of material misstatement of the financial statements due to fraud, and to obtain sufficient appropriate evidence regarding the assessed risks of material misstatements pertain to fraud, through designing and conducting proper responses, and to respond clearly to fraud or suspected fraud which was found during the audit. So, the auditor's responsibilities can be identified in the following points, mandated by international standard No. 240:

1- Each auditor performing audit in accordance with international auditing standards bears a responsibility to ensure that the financial statements audited by him are free from material misstatements, whether resulted from fraud or error. In order to achieve this goal the related literature indicated that auditors may show more efforts in auditing process when they find any indicators in the financial statements as a red flag, Spathis et al (2002) for example pointed out that using discernment analysis and logit regression methods are useful in this aspect, especially when the auditor compare some financial ratios (Total debt / Total assets; inventory / sales) with the previous years and the industry as a whole, in order to identify areas of fraud in the financial statements. Other authors (Shilit, 2002). Suggested that fraud can be detect through matching sales with the corresponding cost of goods sold for each transaction. Other studies have focused on the managers' incentives to practice financial fraud, Mulgan (2004) pointed out that accruals can be manipulated for the benefit of managers who expect to gain rewards on the basis of final outputs of the financial period. Accordingly, they may tend to reduce costs through accruals manipulation, and recording some of current expenses as capital expenses.

Therefore, the experienced auditor can investigate the legality of theses accounting treatments using comparative analysis, and by reference to these processes documents.

2- Because fraud may involve sophisticated and carefully organized schemes designed to conceal practices suchas forgery, deliberate failure to record transactions, or 


\section{Macrothink}

International Journal of Accounting and Financial Reporting ISSN 2162-3082 2015, Vol. 5, No. 1

intentional misrepresentations being made to the auditor, such practices are more difficult to detect especially when accompanied by collusion. In such cases the ability of the auditor to detect the fraud depends on factors related to the auditor's qualifications, skills, experience, and the frequency and extent of manipulation.

3- Although the risk of not detecting fraud by the auditor, especially those of material misstatements committed by the management which are greater than fraud by employees, the auditor will try to obtain a reasonable assurance, then he became responsible for maintaining skepticism throughout the audit. This doubtful will lead the auditor to design Practical procedures to detect such misstatement. And in the currents researchers point of view designing these procedures requires that the auditor specializing in accounting and auditing, has sufficient experience which enables him to discern the intention of fraud, by examining the accounting entries.

Impact of International Standard No. 240 no Auditing Practical Procedures.

Since the international standard No. 240 has imposed on the external auditor the responsibility of ensuring that financial statements audited by him are free from misstatements, whether resulted from manipulation or error, the auditor must make a greater efforts to detect practices that led to distortion of the financial Statements. In order to recognize the efforts made by the auditor for the detection of financial manipulation, the literature indicated a number of audit procedures, such as: (Shilit, 2002)

- Focusing on financial events that have different accounting treatments, such as record maintenance expenses, at the fixed asset account. The purpose of this action is to reduce costs and increase profits, which may lead to request, areward by managers.

- Comparing manager's Salaries with Past year.

- Comparing financial ratios of the company with its counterparts in the market.

- Send support certificates for suppliers to make sure their account balances, in order to ensure the registration of all Purchases futures in inventory account.

According to this debate, the research hypotheses are accepted.

\section{- References:}

1. Chong, sue (2006), The Ethics of creative Accounting, Does it all Add up? Available at www.collinsdictionary.com.

2. Spathis, Ch. Et al (2002), Detecting Falsified Financial Statements: A Comparative Study Using Multi-Criteria Analysis and Multivariate Statistical Techniques, The European Accounting Review 2002, 11:3, 509-533.

3. Kirkos, Efstathios et al (2007), Data Mining Techniques for the Detection of Fraudulent Financial Statements, Expert systems with Applications 32 (2007), $995-1003$.

4. AL-Znaimat (2011), The Impact of actual Audit Quality on the Effectiveness of Financial Statements Fraud Detecting in the Jordanian Auditing Sector, Mu'tah University. Master Theses. 


\section{Macrothink}

International Journal of Accounting and Financial Reporting ISSN 2162-3082 2015, Vol. 5, No. 1

5. Bierstaker, James et al (2006), Accountants' Perceptions Regarding Fraud Detention and Prevention Methods, Managerial Auditing Journal, Vol. 21, No. 5, 2006, PP. 590 - 533.

6. Juma, Ahmad (2008), Auditing for the Purpose of Fraud and embezzlement Discovery, Forum Jordanian and Arab Accountings.

7. Vanten, Gerald (2003) Enronitis - Dispelling the disease, Managerial Auditing Journal, Volume 18, Number 6/7, 2003.

8. Melumad, Nahum and NissimDoron (2008), Foundering and Trends in Accounting, Vol.3, Nos 2-3(2008) 87-221.

9. Abdllautif, Modor (2013), Fraud Risk Factors and Audit Programmed Modifications: Evidence From Jordan, Australasian Accounting Business and Finance Journal, 7(1), 2013, 59-77.

10. Hammersley, Jacquline (2011), A Review and Model of Auditor Judgments in Fraud - Related planning Tasks, A Journal of Practice and Theory, Volume 30, Issue 4 (November 2011) PP. 101-128.

11. Alleyne, Philmore and Howard, Michael (2005), An exploratory study of Auditors' Responsibility for fraud Detection in Barbados, Managerial Auditing Journal, Vol. 20, No. 3, 2005 PP. 284 - 303.

12. Crotty, James (2008), Structural Causes of the Global Financial Cnisis: A Critical Assessment of the new financial Architecture', Working paper 2008-14, University of Massachusetts Amherst.

13. Ismail, Muhammad and Prihatiningtyes, Yene (2014), A Comparative Assessment of Fraud Related Auditing Standards: SA 316 Versus ISA 240. JurnalllmiahMahasiswa FEB 2, No. 1 (2014).

14. Ramos, Michael (2003), Auditor's Responsibility for fraud detection, Journal of Accoumtancy Jan 2003, 195, 1, ABI / In form Global p.g. 28.

15. DiGabriele, James (2008), Implications of Regulatory Prescriptions and Audit Standards on the Evolution of Forensic Accounting in the Audit Process, Montclair State University: School of Business.

16. Spathis, C. (2008), Detecting false Financial Statements Using Published Data: Some evidence from Greece, Managerial Auditing Journal, 17(4), 179-191.

17. Shilit, H. (2002), Financial Shenanigans: How to Detect Accounting Gimmicks and Fraud in Financial Reports, new York, USA: Mc Graw - Hill.

18. Mulgan, R. (2004), Public Sector Reform in New Zealand - Issues of Public Accountability, Technical Report Discussion Paper No. PD Po4 -03, Policy and Governance Program, APSEG, Ana, 2004. 